\title{
Immunohistological and electron microscopical study of nodular fasciitis of the orbit
}

Taiji Sakamoto, Tatsuro Ishibashi, Yoshitaka Ohnishi, Hajime Inomata

\begin{abstract}
We report the case of a 7-year-old Japanese girl with nodular fasciitis which was investigated by immunohistological and electron microscopical methods. An excised nodular lesion in her right orbit showed characteristic histological features of the disease. The fibroblastic cells showed myofibroblastic characteristics, such as immunohistochemically positive reactions against muscle specific actin and vimentin and characteristic electron microscopical appearances. The multinuclear giant cells did not react against any histiocytic markers, including HLA-DR, antimacrophage antigen, lysozyme, and S-100 protein, but the myofibroblastic markers and the electron microscopical study did reveal myofibroblastic characters.
\end{abstract}

Nodular fasciitis is a proliferation of fibroblastic cells and is one of the commonest tumours of fibrous tissue. ${ }^{1}$ Its exact cause is still unknown. However, the disease is benign and does not recur after simple excision. ${ }^{1}$ It is most frequent in the upper limbs, but it is rare in the ocular region and its adnexa. ${ }^{1-10}$

Histologically the lesion has been reported to consist of plump fibroblastic cells, some multinuclear giant cells, and a small amount of mature collagen bundles. ${ }^{1-12}$ Many authors have reported that these fibroblastic cells are myofibroblasts, ${ }^{13}$ but the origin of the multinuclear giant cells is still not clearly understood. ${ }^{311} 12$

We report a case of orbital nodular fasciitis, having used histological, immunohistological, and electron microscopic techniques to study the origins of the fibroblastic cells and multinuclear giant cells.

\section{Case report}

In October 1989 a healthy 7-year-old Japanese girl noticed a slightly painful mass in the right

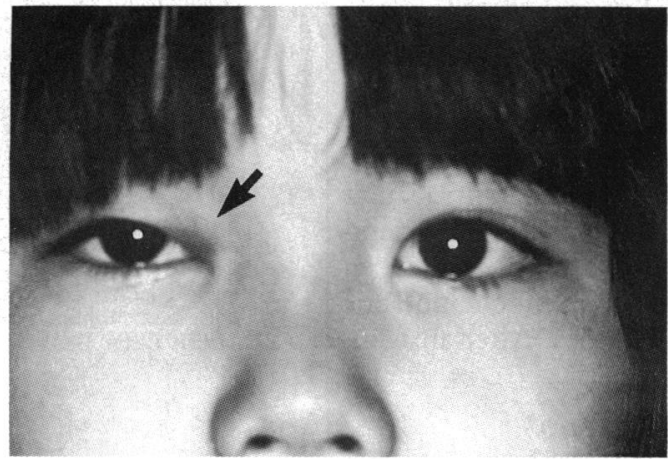

Figure 1 Photograph just before operation. A small mass is seen in the inner canthus of the right eye (arrow). inner canthus of two months' duration. By March 1990 the lesion had grown rapidly and the mass measured $25 \times 15 \mathrm{~mm}$ (Fig 1, arrow). Magnetic resonance imaging showed a solitary nodular mass in the anterior medial part of the right orbit, the hypointense mass on a $\mathrm{T} 1$ weighed image, the hyperintense mass on a T2 weighed image (Fig 2, arrow).

On 20 March 1990 the lesion was excised under general anaesthesia. It was a small nodular mass located in the orbit subcutaneously in the right upper eyelid. Six months after the operation the wound had healed well, leaving only a small remnant of the original mass.

\section{MICROSCOPIC EXAMINATION}

The excised mass was cut in half and promptly fixed with neutralised formalin. The paraffin embedded sections were stained with haematoxylin and eosin.

\section{IMMUNOHISTOCHEMICAL EXAMINATION}

Immunostaining was performed on slides prepared from formalin fixed, paraffin embedded tissue by routine avidin-biotin complex (ABC) methods ${ }^{13}$ using commercially available polyclonal or monoclonal antibodies with Vectastain ABC kits (Vector Laboratories, Buringame, California, USA). Peroxidase activities were developed in 3, 3'-diaminobenzidine tetrahydrochloride medium (Dojin, Tokyo, Japan). The source and dilution of the antibodies used were as follows: Vimentin: (Dakopatts, Glostrup, Denmark, dilution 1:10); keratin: (MA-902; Enzo Biochem, New York, 1:400); muscle specific actin: (HHF35; Transformation Res, Framingham, Massachusetts, USA, 1:8000); S-100 protein: (Dakopatts, 1:500); HLA-DR: (Dakopatts, 1:40); antimacrophage: (MA935; Enzo Biochem, 1:8000); $\alpha-1$ -

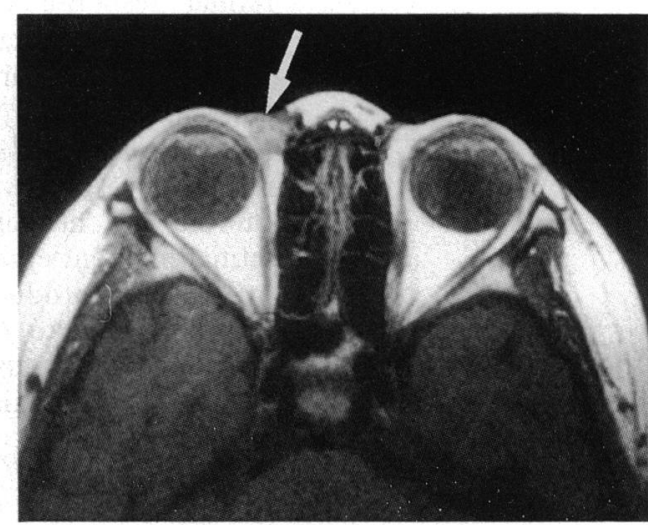

Figure 2 The magnetic resonance on a T2 weighed image. A small solitary mass is seen (arrow).

\footnotetext{
Department of Ophthalmology, Faculty of Medicine, Kyushu University, 3-1-1 Maidashi, Higashi-ku, Fukuoka 812, Japan T Sakamoto T Ishibashi Y Ohnishi Correspondence to: Accepted for publication 15 March 1991
} 


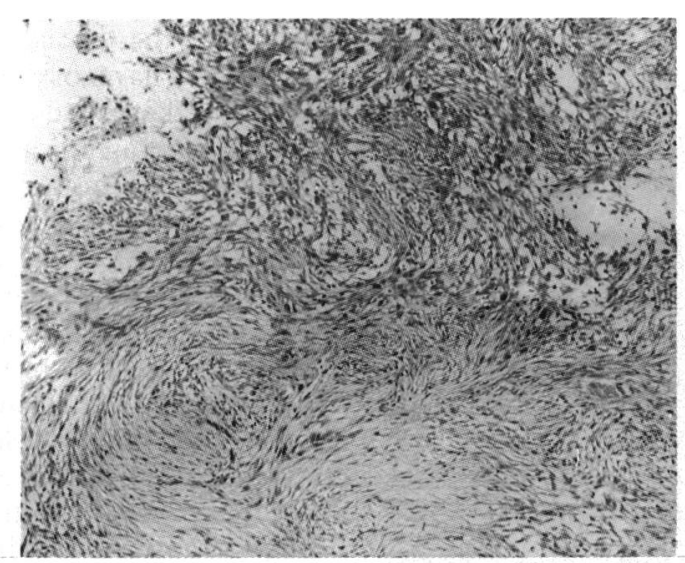

Figure 3 Low power photograph of the lesion. The spindle shaped cells are proliferating haphazardly in the myxomatous background. (Haematoxylin and eosin, $\times 40$.)

antitrypsin: (Dakopatts, 1:400); and lysozyme: (Dakopatts, 1:400). Anti-S-100 protein antibody, antilysozyme antibody, and alpha-1 antitrypsin antibody were rabbit polyclonal antibodies, while the others were mouse monoclonal antibody.

\section{ELECTRON MICROSCOPIC EXAMINATION}

A small fragment of the resected tissue was fixed with $4 \%$ buffered glutaraldehyde solution, postfixed in $1 \%$ osmium tetroxide, dehydrated, and embedded in epoxy resin. Thin sections were stained with uranyl acetate-lead citrate and examined with an electron microscope (JEM100CX, Tokyo, Japan) at an accelerated $80 \mathrm{~K}$

\section{Results}

\section{LIGHT MICROSCOPIC FINDINGS}

The lesion was composed of plump stellate or spindle-shaped fibroblastic cells, arranged in a parallel haphazard fashion (Fig 3). The nuclei of the fibroblastic cells were round to oval, without atypia. Mitotic figures were only rarely observed. An extravasation of the red blood cells was present, and multinuclear giant cells (Fig 4, arrows) were also noticed in the myxomatous stroma.

\footnotetext{
Figure 5

Immunohistological figures shown by antimuscle specific $\operatorname{actin}(H H F-35)$. A: The cytoplasm of the spindle shaped cells was positively stained (arrow). ( $A B C$ method, $\times 350$.) B: The multinuclear giant cell also showed positive reaction products in the cytoplasm. ( $A B C$ method, $\times 400$.)
} voltage.

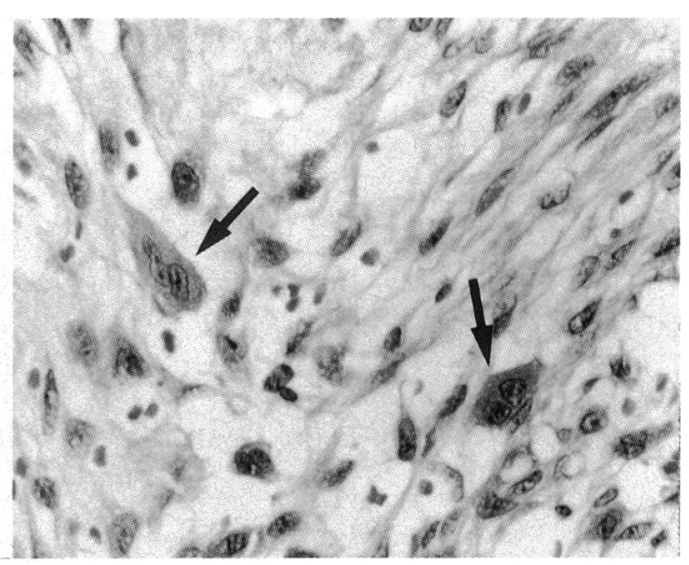

Figure 4 High power photograph of the lesion. The spindle shaped cell has elongated nuclei but lacks atypical mitotic figures. Extravastated red blood cells are seen, together with multinuclear giant cells (arrows). (Haematoxylin and eosin, $\times 375$.)

\section{IMMUNOHISTOCHEMICAL FINDINGS}

The fibroblastic cells reacted positively with antivimentin and antimuscle specific actin antibodies (Fig 5a), while acting negatively with antimacrophage, anti-HLA DR, antikeratin antibodies, and anti-S-100 protein antibodies. Multinuclear giant cells showed a positive reaction against the antivimentin and antimuscle specific actin antibodies (Fig 5 b) but showed a negative reaction to the other markers.

\section{ELECTRON MICROSCOPIC FINDINGS}

The fibroblastic cells had many endoplasmic reticula (Fig 6a). Parallel bundles of actin-like filaments with fusiform densities (Fig 6a, arrows) were present under the plasma membrane. Desmosome-like plaque was noticed between the cells (Fig 6b, arrow).

The multinuclear giant cells had an irregular margin with finger-like processes. A rough endoplasmic reticulum, numerous microfilaments, and dense bodies were also noted in the cytoplasm.

\section{Discussion}

The histopathological study of this case revealed the characteristic findings of nodular fasciitis, such as proliferation of plump spindle-shaped cells located haphazardly within the mucoid
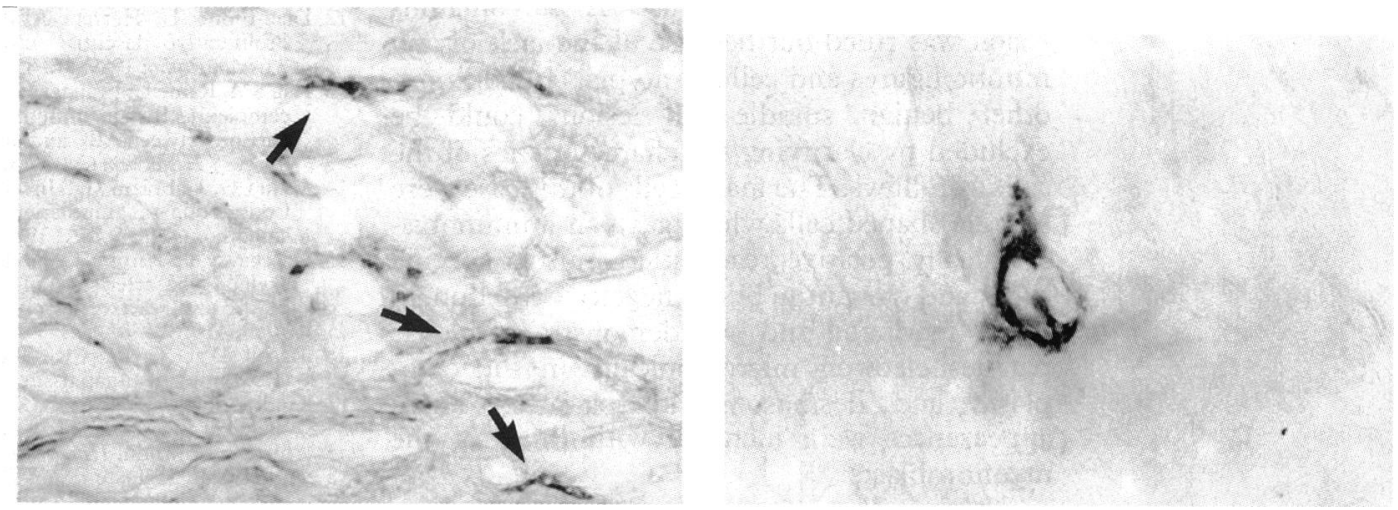

Figure 5A 


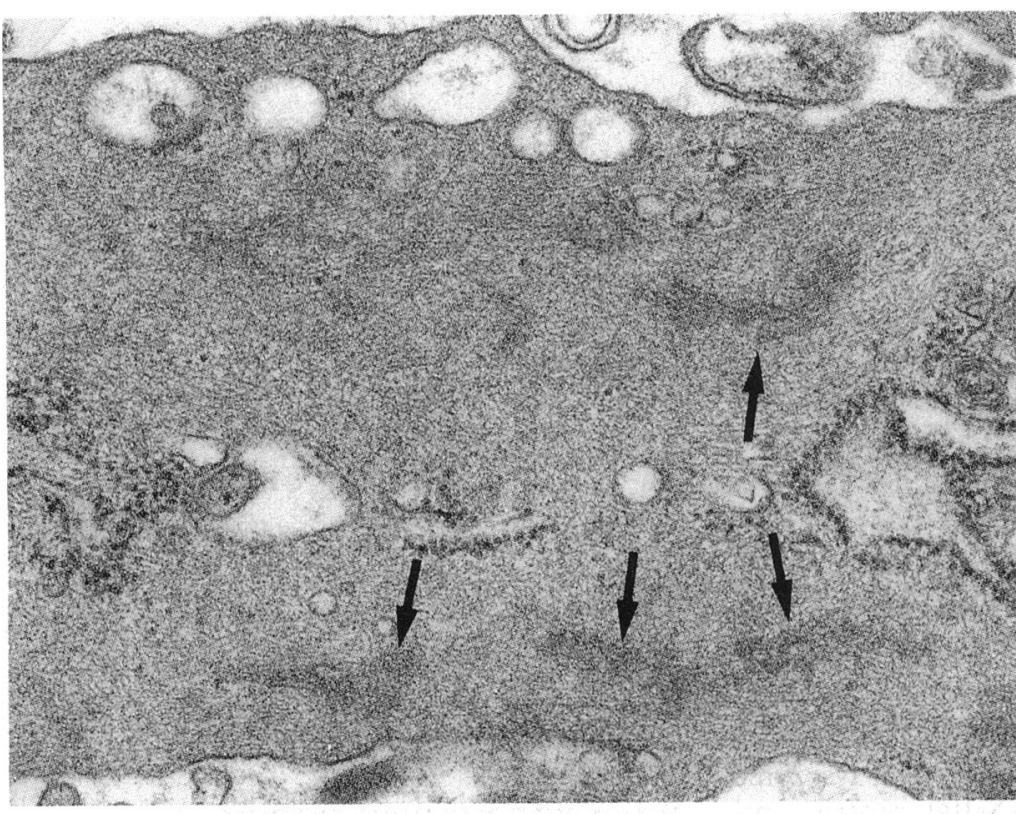

Figure 6 A

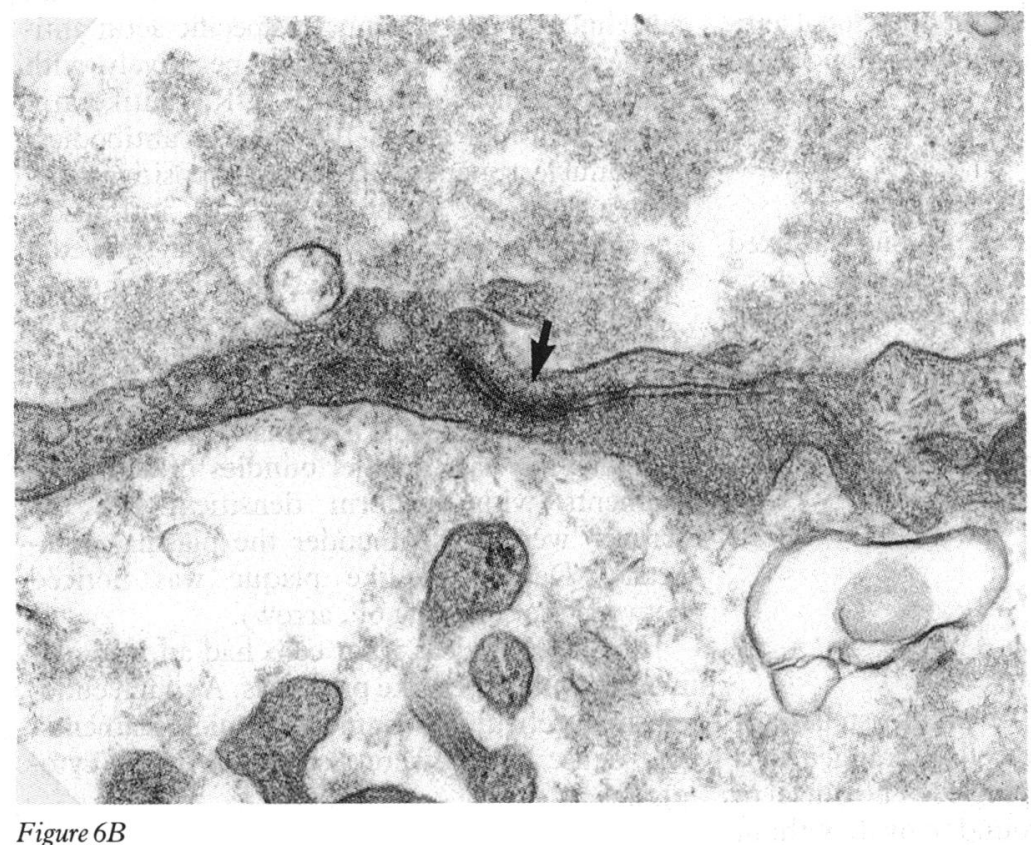

Figure 6 Electron-microscopic figures of the spindle cells. A: Bundles of microfilaments with dense bodies (arrows) running parallel to the long axis of the spindle cells. $(\times 38000) B:$. desmosome-like plaque is present between the spindle shaped cells. $(\times 41000$.

matrix and admixed with many multinuclear giant cells. ${ }^{13}$ These findings have often been mistaken for a sarcomatous lesion or other benign spindle cell lesions.' A sarcomatous lesion was ruled out because of the lack of any mitotic figures and cellular atypia. ${ }^{1}$ In addition, other benign spindle cell lesions could be excluded by clarifying the characteristics of the cells as follows. The major cells of this case were spindle shaped cells which gave an immunohistologically positive reaction to muscle specific actin and vimentin but a negative reaction to other markers, and we demonstrated dense patches electron microscopically in the cytoplasm and desmosome-like plaques. These appearances were identical with those of the myofibroblasts. ${ }^{14}$ is

On the other hand the presence of multinuclear giant cells was one of the histological features of the disease, ${ }^{1-12}$ and these cells were believed to have originated from histiocytes. Recently Okaye and Watanabe reported from electron microscopical findings ${ }^{11}$ that multinuclear cells in this lesion originated from myofibroblasts. Diaz-Flores et al also suggested that both fibroblastic cells and multinuclear cells originate from vascular pericytes. ${ }^{12}$ However, the exact origin of these cells has yet to be elucidated. Immunohistochemically the multinucleate giant cells showed a positive reaction against the antimuscle specific actin and vimentin but a negative reaction against, antimacrophage, $\alpha$-1-antitrypsin, lysozyme and HLA-DR antibodies, which usually reacted with macrophages. ${ }^{16-18}$ The lack of any positive immunohistochemical staining might sometimes be due to poor fixation and embedding procedures, though a positive reaction of the macrophages in the same section further suggested a negative reaction of those giant cells. Electron microscopically the giant cells showed numerous peripheral microfilaments with dense bodies and endoplasmic reticulum, which are a feature of smooth muscle cells. ${ }^{1114} 15$

It might be true that some giant cells showed different immunohistological reactivities (antimuscle specific actin negative) so these possibilities still do not exclude the fact that multinuclear giant cells may have various other different origins. However, in considering both the immunohistological and electron microscopic findings together, we could say at least that some of the multinuclear giant cells originated from the myofibroblasts.

1 Enzinger FM, Weiss SW. Benign tumors and tumorlike lesion of fibrous tissue. Soft tissue tumors. St Louis: Mosby, 1988: of fibrous

2 Font RL. Nodular fasciitis. Eyelid and lacrimal drainage system. In: Spencer WH, ed. Ophthalmic pathology. Philadelphia: Saunders, 1986: 2290-36.

3 Wirman JA. Nodular fasciitis, a lesion of myofibroblasts. Cancer 1976; 38: 2378-89.

4 Font RL, Zimmermann LE. Nodular fasciitis of the eye and adnexa. Arch Ophthalmol 1966; 75: 475-81.

5 Perry RH, Ramani PS, Mcallister V, Kalbag RM, Kanagasundaram CR. Nodular fasciitis causing unilateral proptosis. Br f Ophthalmol 1975; 59: 404-8.

proptosis. Br f Ophthalmol 1975; 59: 404-8.
6 Tolls RE, Mohr S, Spencer WH. Benign nodular fasciitis originating in Tenon's capsule. Arch Ophthalmol 1966; 75: originating

7 Levit JM, deVeer JA, Oguzham MC. Orbital nodular fasciitis. Arch Ophthalmol 1969; 81: 235-7.

8 Foos RY. Eye and adnexa. In: Coulson WF, ed. Surgical pathology. Philadelphia: Lippincott, 1988: 1659-60.

9 Schmidt JGH, Kruerger GRF, Brusis T. Nodulare Fasziitis der Orbita. Klin Monatsbl Augenheilkd 1984; 184: 213-5.

10 Meacham CT. Pseudosarcomatous fasciitis. Am $\mathcal{F}$ Ophthalmol 1977; 77: 747-9.

11 Okaye MI, Watanabe I. Ultrastructural and immunohistochemical investigations of the giant cells in nodular fasciitis. chemical investigations of the giant

12 Diaz-Flores L, Herrera AIM, Montelengo RG, Garcia G. Proliferative fasciitis: ultrastructure and histogenesis. F Cutan Pathol 1989; 16: 85-92.

13 Hsu SM, Raine L, Franger H. Use of avidin-biotin-peroxidase complex $(\mathrm{ABC})$ in immunoperoxidase techniques: a comparison between $A B C$ and unlabelled antibody (PAP) procedures. $\mathcal{F}$ Histochem Cytochem 1981; 29: 577-80

14 Majno G, Gabbiani G, Hirschel BJ, Ryan GB, Statkov PR. Contraction of granulation tissue in vitro - similarity to smooth muscle. Science 1971; 173: 548-9.

15 Hasegawa T, Hirose T, Kudo E, Abe J, Hizawa K. Cytoskeletal characteristics of myofibroblasts in benign neoplastic and reactive fibroblastic lesions. Virchows Arch $(A)$ 1990; 416: 375-82.

16 Mason DY, Taylor CR. The distribution of muramidase (lysozyme) in human tissues. $\mathcal{F}$ Clin Pathol 1975; 28: 124-32.

17 Kindblom L, Jacobsen GK, Jakobsen M. Immunohistochemical investigations of tumor of supposed fibroblasticchemical investigations of tumor of supposed fibro

18 Smith MEF, Holgate CS, Williamson JMS, Grigor I, Quirke P, Bird CC. Major histocompatibility complex class II antigen expression in $B$ and $T$ cell non-Hodgkin's lymphoma. $\mathcal{O}$ Clin Pathol 1987; 40: 34-41. 